\title{
T. Karanovic
}

\section{Arenopontia (Neoleptastacus) huysi, sp. nov. (Crustacea, Copepoda, Harpacticoida) from marine interstitial of Montenegro (S.E. Europe)}

Received: 20 March 1999 / Received in revised form: 15 September 1999 / Accepted: 21 September 1999

\begin{abstract}
A new species of Arenopontia (Neoleptastacus) is described on the basis of a single female collected from one sandy beach in Montenegro, Adriatic Sea. With the addition of the new species, the subgenus Neoleptastacus now includes 18 species throughout the world. At the end of this paper there is a key for their determination.
\end{abstract}

Key words Copepoda $\cdot$ Arenopontia $\cdot$ Neoleptastacus . Montenegro $\cdot$ Taxonomy

\section{Introduction}

Intensive investigation of the marine interstitial Harpacticoida was started during the 1930s (Nicholls 1935; Wilson 1935). During this time Kunz (1937) established the genus Arenopontia from both sexes of A. subterra$n e a$, which he described from the German coast. Later, from Australia, Nicholls (1945) established the genus Neoleptastacus from one new species which he named $N$. spinicaudatus (also from both sexes). Unfortunately Nicholls' genus was not included in the harpacticoid world monograph of Lang (1948). Perhaps because of that Chappuis (1952) described one new species from Madagascar in the genus Arenopontia (A. australis), although it was obvious that the new species belonged to the genus Neoleptastacus. Later, Chappuis (1954a) cited Nicholls' paper when he described another new species (A. acantha), but strangely he did not mention the genus Neoleptastacus. Finally, he cited Nicholls' paper correctly (Chappuis 1954b) and synonymized the genus Neoleptastacus with Arenopontia when he described another new species (A. longiremis). His opinion, although it was

Communicated by H.-D. Franke

T. Karanovic ( $)$

Institute of Marine Biology, P.O. Box 69, Kotor 85335,

Montenegro, Yugoslavia Tel./Fax: +381-82-11822

Present address:

c/o Accursio Venezia, Via Brescia 3,

I-84092 Bellizzi (SA), Italy (Tel.: +39-0828-355-335) very problematic, was supported by many authors (Noodt 1955; Chappuis and Delamare Deboutteville 1956; Chappuis 1958; Chappuis and Rouch 1961; Bodin 1967; Bozic 1967; Rao 1967; Ito 1968; Masry 1970; Cottarelli 1973; Mielke 1987). The generic status of Neoleptastacus was supported only by Krishnaswamy (1957). As a compromise, Wells (1967) proposed a subgeneric status for Neoleptastacus, within the range of the genus Arenopontia.

That compromise has been approved until now (Kunz 1971; Ito 1978; Bodiou and Colomines 1986; Wells 1986; Apostolov and Marinov 1988; Cottarelli et al. 1994; Martinez Arbizu and Moura 1994; Huys and Conroy-Dalton 1996). Now the subgenus Neoleptastacus includes 18 species from all over the world. At the end of this paper is a key to their determination. They are mostly marine-inhabiting interstitial, but two of them have also been discovered in freshwater interstitial (Cottarelli et al. 1994). The high level taxonomy of the genus Arenopontia (subg. Neoleptastacus) is more problematic. In the beginning (Kunz 1937; Nicholls 1945) it was placed in the family Canthocamptidae. Lang (1948) transferred it to the family Cylindropsyllidae, into the newly created subfamily Leptopontiinae. After Lang's monograph many new genera of the family Cylindropsyllidae were described, and the subfamily concept was no longer tenable (Huys and Conroy-Dalton 1993). Huys (1992) elevated one of Lang's subfamilies to the family status (Leptastacinae). After that, Martinez Arbizu and Moura (1994) raised Lang's subfamily Leptopontiinae to family status and included the subfamilies Leptopontiinae, Psammopsyllinae and a new subfamily Arenopontiinae (in which was placed only the genus Arenopontia). In that revision the subfamily Cylindropsyllinae was allocated to the family Canthocamptidae. A similar opinion was presented later by Moura and Pottek (1998). We support that revision, although Huys and Conroy-Dalton (1996) criticized it, because it emphasizes the importance of the furcal appearance. We just cannot agree with dissolving the family Cylindropsyllidae and allocating it to the Canthocamptidae.

During an investigation of the copepod fauna in Montenegro, one undescribed species of the genus Arenopon- 
tia was identified. This new species, which belongs to the subgenus Neoleptastacus, is herein described as A. (N.) huysi sp. nov.

\section{Methods}

A sample was collected by the Karaman-Chappuis method from a sandy beach on the island of Ada Bojana, Montenegro, Adriatic Sea. The material was preserved by adding several drops of $36 \%$ formaldehyde, and very soon after that it was washed, and copepods were separated and placed in $70 \%$ ethanol. The specimen was dissected in a mixture of distilled water and glycerol (1:1), with fine entomological needles. All drawings were prepared using a drawing attachment on a Leica DMLS microscope with C-PLAN achromatic objectives. Dissected appendages were preserved in Faure's medium, which is prepared following the old procedure, recently discussed by Stock and Vaupel Klein (1996). Abbreviations used in the text, the key, and the figure legends are: A1 antennula; A2 antenna; Enp endopodite; Enp2P3 second endopodite segment of the third leg; Exp exopodite; $F u$ furca; $G S$ genital somite; $M d$ mandibula; $M x$ maxilla; $M x l$ maxillula; Mxp maxilliped; P1-5 first to fifth leg; Ro rostrum.

\section{Results}

\section{Taxonomy part}

Family Leptopontiidae Lang, 1948

Subfamily Arenopontiinae Martinez Arbizu \& Moura, 1994

Genus Arenopontia Kunz, 1937

Subgenus Neoleptastacus Nicholls, 1945

Arenopontia (Neoleptastacus) huysi, sp. nov.

\section{Material examined}

A single female (holotype) from a sandy beach on the island of Ada Bojana (41 $\left.51^{\prime} 30^{\prime \prime} \mathrm{N}, 19^{\circ} 21^{\prime} 10^{\prime \prime} \mathrm{E}\right)$, near the town of Ulcinj, Montenegro, Adriatic Sea, was collected by T. Karanovic on 13 May 1998. The specimen was completely dissected, mounted on a slide in Faure's medium, and deposited in the author's collection (no. 8/100/0625) at the Institute of Marine Biology, Kotor, Montenegro.

\section{Description}

Female (holotype). Body length $0.32 \mathrm{~mm}$ measured from tip of rostrum to rear margin of furcal rami. Body elongate, cylindrical, without distinct separation between prosome and urosome but with clear somite boundaries (Fig. 5). Thoracic somites connected by well-developed arthrodial membranes, as well as between last thoracic and first abdominal somites. Nauplius eye wanting. Hind margins of all body somites smooth. First, second and third free thoracic somites with a chitinous suture dorsolaterally, which bears a row of very fine spinules (Fig. 5). Genital double-somite about 1.5 times longer
Table 1 Spine and setal formula on exopodites and endopodites P1-P4 (inner/outer spine or seta; inner/terminal/outer)

\begin{tabular}{lllllll}
\hline Segments & Exp & & & & \multicolumn{2}{c}{ Enp } \\
\cline { 2 - 3 } \cline { 6 - 7 } & 1 & 2 & 3 & & 1 & 2 \\
\hline P1 & $0 / 1$ & $0 / 0$ & $0 / 2 / 1$ & & $1 / 0$ & $0 / 2 / 0$ \\
P2 & $0 / 1$ & $0 / 1$ & $0 / 2 / 1$ & & $0 / 0$ & $1 / 2 / 0$ \\
P3 & $0 / 1$ & $0 / 1$ & $0 / 2 / 1$ & & $0 / 0$ & $0 / 2 / 0$ \\
P4 & $0 / 1$ & $0 / 1$ & $1 / 2 / 1$ & & $0 / 0$ & $0 / 2 / 0$ \\
\hline
\end{tabular}

than wide, without any trace of subdivision, and with no seta representing rudimental sixth leg (Fig. 1). Anal somite furnished with an arched spur-shaped process on both lateral sides of anal operculum (Fig. 5). Anal operculum concave, smooth, and short (Fig. 12). Furcal ramus approximately three times as long as proximal width, distinctly tapering posteriorly (Fig. 13). Its outer distal corner produced into backwardly directed, dorsally recurved spinous process (Fig. 5). So-called principal terminal seta arising from a ledge located on last fourth of furcal length, and about 3.8 times longer than furcal ramus (Figs. 12, 13). This seta is accompanied by another thin one (Fig. 13). Of the three setae arising from dorsal side, inner one of proximal two is aesthetasc-like, and almost twice shorter than outer seta (Fig. 12). Distal dorsal seta is somewhat longer than outer proximal one, and with normal appearance. All furcal setae are naked. Rostrum not exceeding first antennular segment, without any sensillae, and very pointed (Fig. 2). A1 long, sixsegmented, with aesthetascs on fourth and last segments (Fig. 2), and with following formula of setal number from proximal end: 0.4.3.1.2.7. Second segment the longest, as long as the next three ones together. A2 with short and unornamented coxa, and with allobasis about 2.3 times longer than wide (Fig. 3). Exopodite represented by small cylindrical process which attaches near proximal end of allobasis and terminates in a simple seta. Distal endopodite segment almost as long as allobasis, furnished with three geniculate spines, one simple spine on distal end, and two short spines on lateral side (Fig. 3). Md with well-developed gnathobase of coxa bearing several teeth and one seta. Md palp uniramous, two-segmented, with one lateral and three terminal setae on distal segment (Fig. 9). Mxl and Mx were damaged when dissected, and could not be observed. Mxp threesegmented, without any ornamentation. All swimming legs with three-segmented exopodites and two-segmented endopodites (Figs. 6-8, 10, 11). Spine and setal formula on exopodites and endopodites $\mathrm{P} 1-\mathrm{P} 4$ as shown in Table 1. First endopodite segment of P4 about 3.5 times longer than second (Fig. 6). That ratio is 1.7 for P3 (Fig. 7), 1.2 for P2 (Fig. 11), and 1.5 for P1 (Fig. 10). Terminal setae on Enp2P4 are almost equal in length, while on Enp2P3 and Enp2P2 inner seta is much longer than outer one. P5 represented by almost triangular plate, because its inner distal corner prolonged in a strong and slightly curved tip (spur-shaped process). It bears two 
Figs. 1-5 Arenopontia (Neoleptastacus) huysi, sp. nov., holotype (female, $0.32 \mathrm{~mm}$ ). 1 GS; 2 A1 and Ro; 3 A2; 4 P5; 5 habitus, lateral view. Scales $0.1 \mathrm{~mm}$
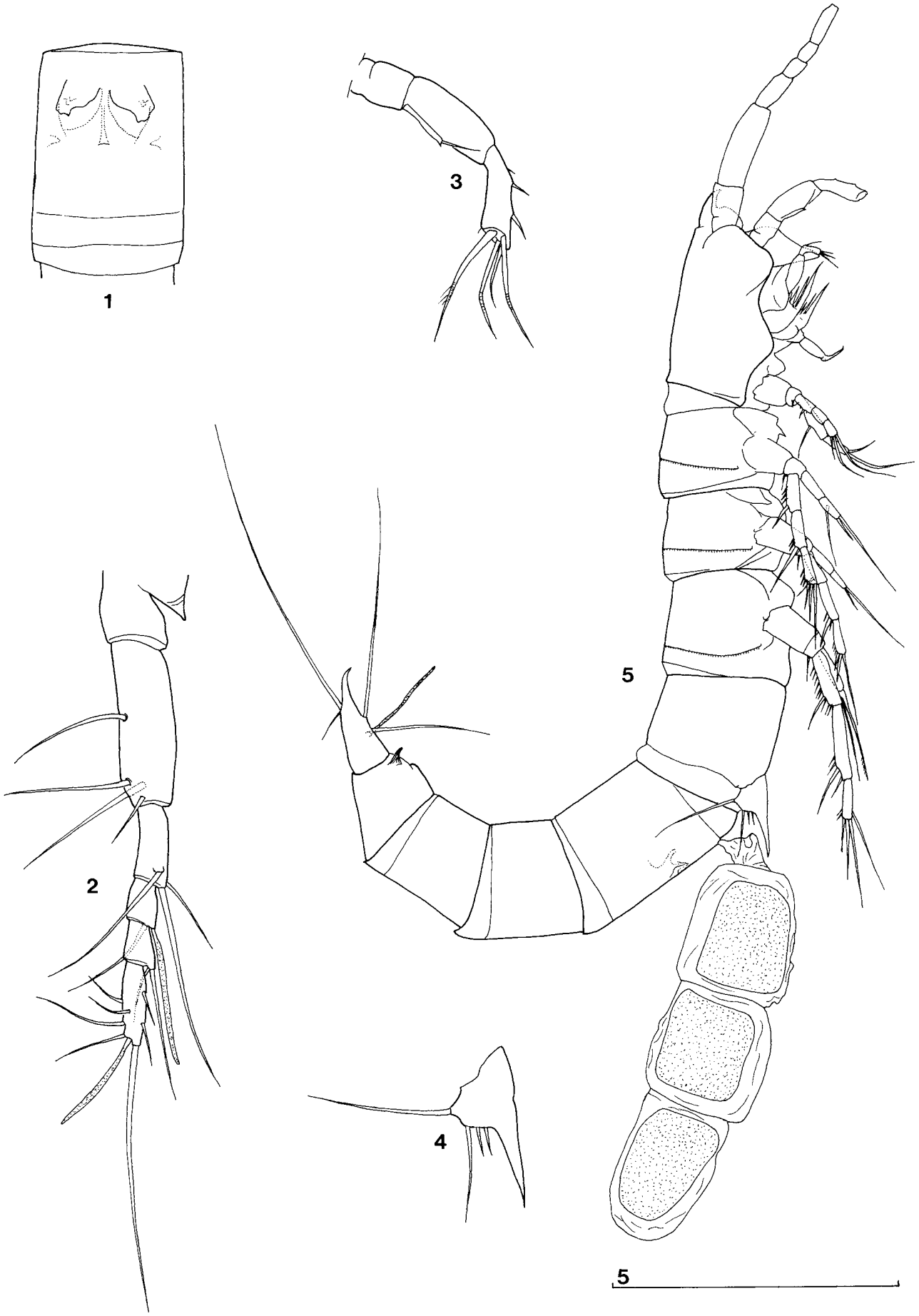

$1-4$

short and one long seta on distal edge, as well as one very long seta on the outer corner (Fig. 4). Single linear egg-sac consists of three large eggs (Fig. 5).

\section{Etymology}

The specific name is dedicated to Dr. Rony Huys, copepodologist from the Natural History Museum in London, in grateful acknowledgement of the great help he provided with the references for this paper. It is a noun in the genitive singular.

\section{Discussion}

According to the shape of P1 (last exopodite segment bearing only three setae and spines) Arenopontia (Neo- 
Figs. 6-13 Arenopontia (Neoleptastacus) huysi, sp. nov., holotype (female, $0.32 \mathrm{~mm}$ ). 6 P4; 7 P3; 8 ExpP1; 9 Md palp; 10 EnpP1; 11 P2; 12 last abdominal somite and $\mathrm{Fu}$, dorsal view; 13 last abdominal somite and $\mathrm{Fu}$, ventral view. Scales $0.1 \mathrm{~mm}$
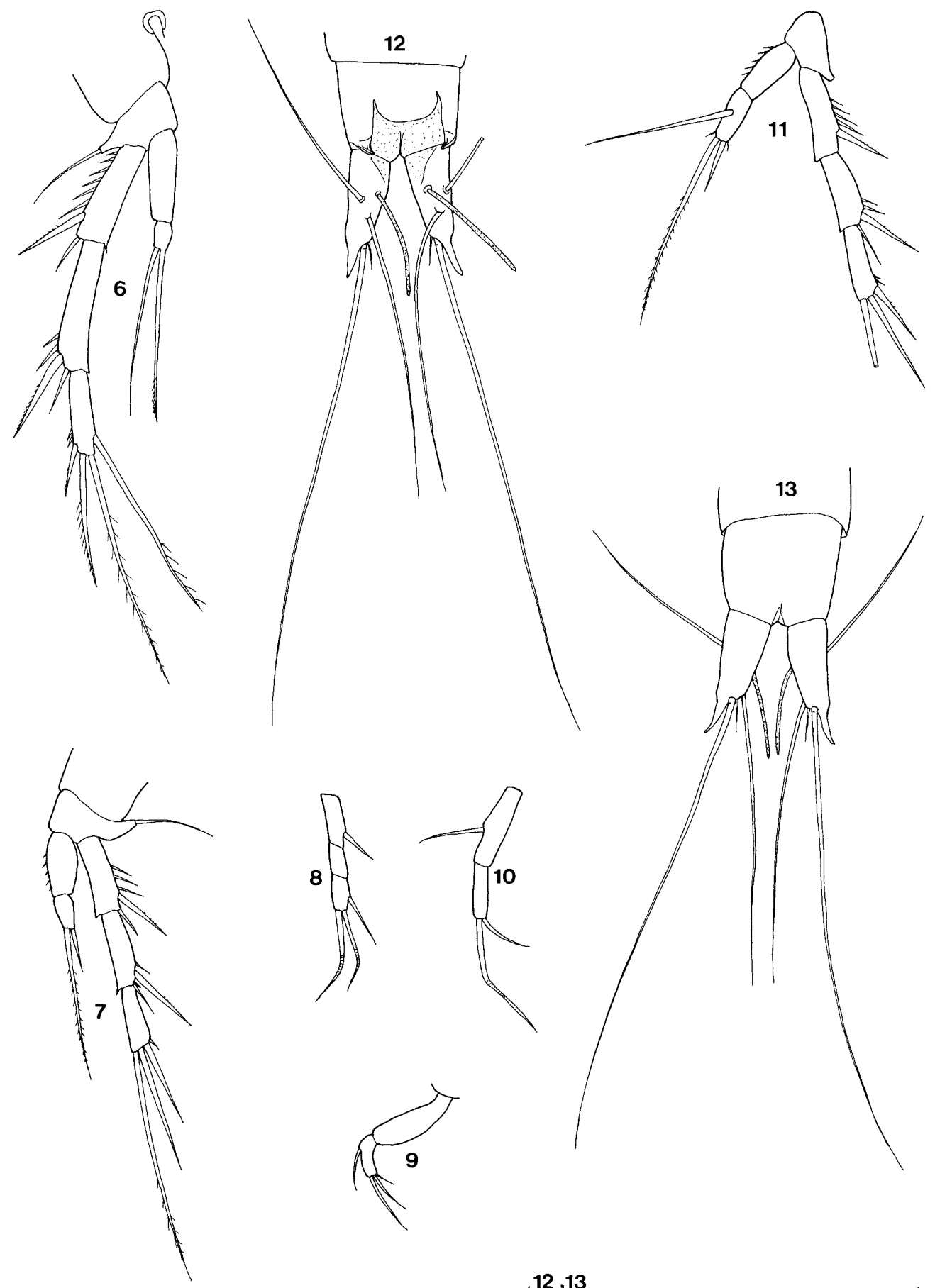

12,13

\section{$6-11$}

leptastacus) huysi, sp. nov. is similar to $A .(N$.$) ang-$ olensis Kunz, 1971 and A. (N.) africana Chappuis \& Rouch, 1961. From both species $A$. (N.) huysi is clearly distinguishable by the shape of EnpP2 and EnpP3 (twosegmented instead of one-segmented), as well as by the shape of the anal operculum [pointed in $A$. (N.) africana and $A$. (N.) angolensis]. Also, A. (N.) africana has a very specific P5, with only two setae. All other species in the subgenus Neoleptastacus have the last exo- podite segment of P1 with four setae and spines. $A .(N$. australis Chappuis, 1952 differs from the new species by the one-segmented endopodite of P3, as well as by the shape of A1 and Fu. By the presence of two setae on the Enp2P3 A. (N.) huysi is very easily distinguishable from A. (N.) longiremis Chappuis, 1954, A. (N.) accraensis Lang, 1965, A. (N.) indica Rao, 1967, A. (N.) gussoae Cottarelli, 1973, A. (N.) sakagamii Ito, 1978, A. (N.) reductaspina Mielke, 1987, A. (N.) phrea- 
tica Cottarelli et al. (1994), and A. (N.) speluncae Cottarelli et al. 1994, which have only one seta in that article. A. (N.) spinicaudata (Nicholls, 1945) is similar to A. (N.) huysi by the shape of P2-P5, but they are evidently distinguishable by the shape of $\mathrm{Fu}, \mathrm{A} 1$, and $\mathrm{P} 1$. It is the same situation with $A$. $(N$.) secunda (Krishnaswamy 1957), but this species is very poorly described. A. (N.) ishikariana Ito, 1968, from Japan, is similar to the new species by the shape of P2-P5, but it differs by the shape of Md palp, hind margins of abdominal somites, and A1. A. (N.) chaufriassei Bodiou \& Colomines, 1986 and A. (N.) ornamenta Mielke, 1987 are clearly distinguishable from the new species by the shape of P5 (reduced number of setae), as well as by other characteristics. A. (N.) huysi sp. nov. is probably most similar to A. (N.) acantha Chappuis, 1954, which was described from several localities in the Mediterranean Sea, and later found also all over the Mediterranean, in India, and in the United States (Bozic 1967; Masry 1970; Wells 1986). These two species differ by the shape of $\mathrm{Fu}$ [there is no aesthetasc in $A$. (N.) acantha], A1, and of course P1. There are, moreover, differences between them, but they are not emphasized here because of the great variability of $A$. (N.) acantha. Here we give the key to species of the subgenus Neoleptastacus, although Bodiou \& Colomines (1986) have already given an excellent key, because five species have been described in the meantime. So, now this subgenus includes 18 species.

\section{Key to species of the subgenus Neoleptastacus}

1. Exp3P1 with 3 setae or spines Exp3P1 with 4 setae or spines

2. EnpP2 and EnpP3 1-segmented EnpP2 and EnpP3 2-segmented

3. Enp2P4 with 2 setae Enp2P4 with only 1 seta

A. (N.) angolensi, sp. nov.

4. EnpP3 2-segmented EnpP3 1-segmented

5. Enp1P2 with 1 inner seta Enp1P2 unarmed

6. Enp2P3 with 2 setae

Enp2P3 with only 1 seta

7. Enp2P2 with 2 setae Enp2P3 with 3 setae

8. Enp2P3 with 1 seta Enp2P3 with 2 setae

9. P5 bears only 3 setae

P5 bears 4 setae

10. Enp2P3 with 1 seta Enp2P3 with 2 setae

11. Spur-shaped process of P5 smooth Spur-shaped process of P5 spinulose

12. Furcal ramus without lateral spine Furcal ramus with lateral spine

Chappuis \& Rouch, 1961

A. (N.) australis

Chappuis, 1952

(Krishnaswamy, 1957)

A. (N.) phreatica Cottarelli et al. 1994

A. (N.) ornamenta Mielke, 1987

A. (N.) reductaspina Mielke, 1987

A. (N.) speluncae Cottarelli et al. 1994

A. (N.) gussoae Cottarelli, 1973
13. Proximal-lateral seta on $\mathrm{Fu}$ transformed into the easthetasc This seta nontransformed

14

14. Enp1P1 unarmed

Enp1P1 with 1 inner seta

A. (N.) longiremis Chappuis, 1954

A. (N.) accraensis Lang, 1965

A. (N.) sakagamii Ito, 1978

15. P5 with 4 setae P5 with 2 setae and 1 short spine

16. Exp3P4 with 4 setae or spines Exp3P4 with 3 setae or spines

17. Anal somite with spur-shaped process on both lateral sides of anal operculum Anal somite without those processes

A. (N.) chaufriassei Bodiou \& Colomines, 1986

A. (N.) spinicaudata (Nicholls, 1945)

A. (N.) acantha Chappuis, 1954

A. (N.) ishikariana Ito, 1968

\section{References}

Apostolov A, Marinov TM (1988) Fauna Bulgarica, 18 Copepoda, Harpacticoida. Academiae Scientiarum Bulgaricae, Sofia

Bodin P (1967) Catalogue des nouveaux Copepodes Harpacticoides marins. Mem Mus Nat Hist Nat 50:1-76

Bodiou J-I, Colomines J-C (1986) Harpacticoides (Crustaces, Copepodes) des Iles Crozet, I. Description d'une espece nouvelle du genre Arenopontia Kunz. Vie Milieu 36:55-64

Bozic B (1967) Deux Copepodes Harpacticoide de l'Inde. Bull Mus Nat Hist Nat 38:869-873

Chappuis PA (1952) Copepodes Harpacticoides psammiques de Madagascar. Mem Inst Sci Madagascar 7:145-160

Chappuis PA (1954a) Harpacticides psammiques recoltes per $\mathrm{Cl}$. Delamare Deboutteville en Mediterranee. Vie Milieu 4:254276

Chappuis P-A (1954b) Recherches sur la faune interstitielle des sediments marins et d'eau douce à Madagascar. IV. Copepodes Harpacticoides psasmmiques de Madagascar. Mem Inst Sci Madagascar 9:45-73

Chappuis PA (1958) Harpacticoides psammiques marins des environs de Seattle (Washington, USA). Vie Milieu 8:409-422

Chappuis PA, Delamare Deboutteville C (1956) Etudes sur la faune interstitielle des iles Bahamas recoltee par madame Renaud-Debyser, I. Copepodes et Isopodes. Vie Milieu 7:373396

Chappuis PA, Rouch R (1961) Harpacticides psammiques d'une plage pres d'Accra (Ghana). Vie Milieu 11:605-614

Cottarelli V (1973) Arenopontia gussoae sp. nov., nuovo arpacticoide di acque interstiziali litorali dell' isola di Cuba. Frag Entomol 9:49-59

Cottarelli V, Bruno MC, Venanzetti F (1994) First record in phreatic freshwater of harpacticoids belonging to the genus Arenopontia (Crustacea, Copepoda) and description of two new species. Ann Mus Civ Stor Nat Giacomo Doria 90:471-484

Huys R (1992) The amphiatlantic distribution of Leptastacus macronyx (T. Scott, 1892) (Copepoda: Harpacticoida): a paradigm of taxonomic confusion; and a cladistic approach to the classification of the Leptastacidae Lang, 1948. Meded K Acad Wet, Lett Schone Kunsten Bel 54:21-196
Huys R, Conroy-Dalton S (1993) Willemsia gen. nov. and Boreopontia Willems, 1981 revisited (Harpacticoida: Cylindropsyllidae). Sarsia 78:273-300

Huys R, Conroy-Dalton S (1996) A revision of Leptopontia T. Scott (Copepoda: Harpacticoida) with description of six new species. Zool J Linn Soc 118:197-239

Ito $\mathrm{T}$ (1968) Descriptions and records of marine harpacticoid copepods from Hokkaido. J Fac Sci, Hokkaido Univ, Ser 6 16: 369-381

Ito T (1978) A new species of marine interstitial harpacticoid copepod of the genus Arenopontia from the Bonin Islands, southern Japan. Annot Zool Jpn 51:47-55 
Krishnaswamy S (1957) Studies on the Copepoda of Madras. University of Madras, Madras

Kunz H (1937) Zur Kenntnis der Harpacticoiden des Küstengrundwassers der Kieler Förde. Kiel Meeresforsch 2:95-115

Kunz H (1971) Harpacticoiden (Crustacea Copepoda) von einem Sandstrand Angolas. Zool Anz 186:348-359

Lang K (1948) Monographie der Harpacticiden. Hakan Ohlssons Boktryckeri, Lund

Martinez Arbizu P, Moura G (1994) The phylogenetic position of the Cylindropsyllinae Sars (Copepoda, Harpacticoida) and the systematic status of the Leptopontiinae Lang. Zool Beit Neue Folge 35:55-77

Masry D (1970) Ecological study of some sandy beaches along the Israeli Mediterranean coast, with a description of the interstitial harpacticoids (Crustacea, Copepoda). Cah Biol Mar 11:229258

Mielke W (1987) Interstitielle Copepoda von Nord- und SüdChile. Microfauna Mar 3:309-361

Moura G, Pottek M (1998) Selenopsyllus, a new genus of Cylindropsyllinae (Copepoda, Harpacticoida) from Atlantic and Antarctic deep waters. Senckenb Marit 28:185-209
Nicholls AG (1935) Copepods from the interstitial fauna of sandy beach. J Mar Biol Assoc UK 20:379-405

Nicholls AG (1945) Marine Copepoda from Western Australia, IV. Psammophilous Harpacticoids. J R Soc West Aust 29:17-24

Noodt W (1955) Harpacticiden (Crust. Cop.) aus dem Sandstrand der französischen Biscaya-Küste. Kiel Meeresforsch 11:86109

Rao GC (1967) On the life-history of a new sand dwelling harpacticoid copepod. Crustaceana 13:129-136

Stock JH, von Vaupel Klein JC (1996) Mounting media revisited: the suitability of Reyne's fluid for small crustaceans. Crustaceana 69:794-798

Wells JBJ (1967) The littoral Copepoda (Crustacea) of Inhaca Island, Mozambique. Trans R Soc Edinb 67:189-358

Wells JBJ (1986) Copepoda: marine-interstitial Harpacticoida. In: Botosaneanu L (ed) Stygofauna Mundi. EJ Brill/Dr W Bachuys, Leiden, pp 356-381

Wilson CB (1935) A new and important copepod habitat. Smithson Misc Collect 94:1-13 